
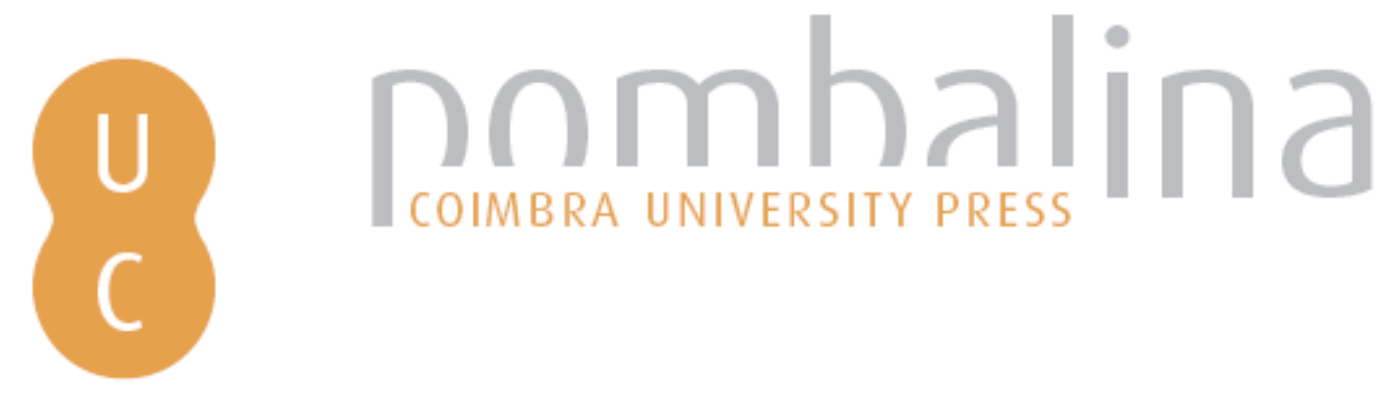

\title{
Multi-scale geometrical analysis of fracture networks in granite massifs and its application to landfill site selection
}

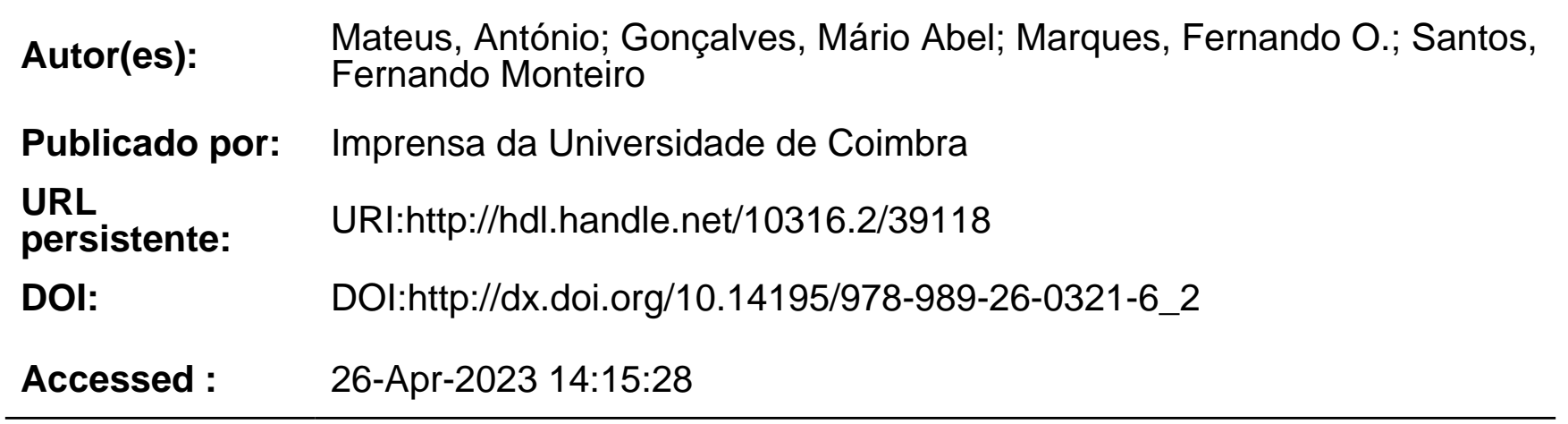

A navegação consulta e descarregamento dos títulos inseridos nas Bibliotecas Digitais UC Digitalis, UC Pombalina e UC Impactum, pressupõem a aceitação plena e sem reservas dos Termos e Condições de Uso destas Bibliotecas Digitais, disponíveis em https://digitalis.uc.pt/pt-pt/termos.

Conforme exposto nos referidos Termos e Condições de Uso, o descarregamento de títulos de acesso restrito requer uma licença válida de autorização devendo o utilizador aceder ao(s) documento(s) a partir de um endereço de IP da instituição detentora da supramencionada licença.

Ao utilizador é apenas permitido o descarregamento para uso pessoal, pelo que o emprego do(s) título(s) descarregado(s) para outro fim, designadamente comercial, carece de autorização do respetivo autor ou editor da obra.

Na medida em que todas as obras da UC Digitalis se encontram protegidas pelo Código do Direito de Autor e Direitos Conexos e demais legislação aplicável, toda a cópia, parcial ou total, deste documento, nos casos em que é legalmente admitida, deverá conter ou fazer-se acompanhar por este aviso.

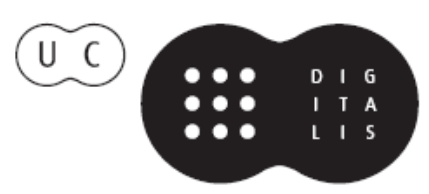


MARTIM PORTUGAL V. FERREIRA

Coordenação

\section{A Geologia de Engenharia e os Recursos Geológicos} VOL. 1 - GEOLOGIA DE ENGENHARIA

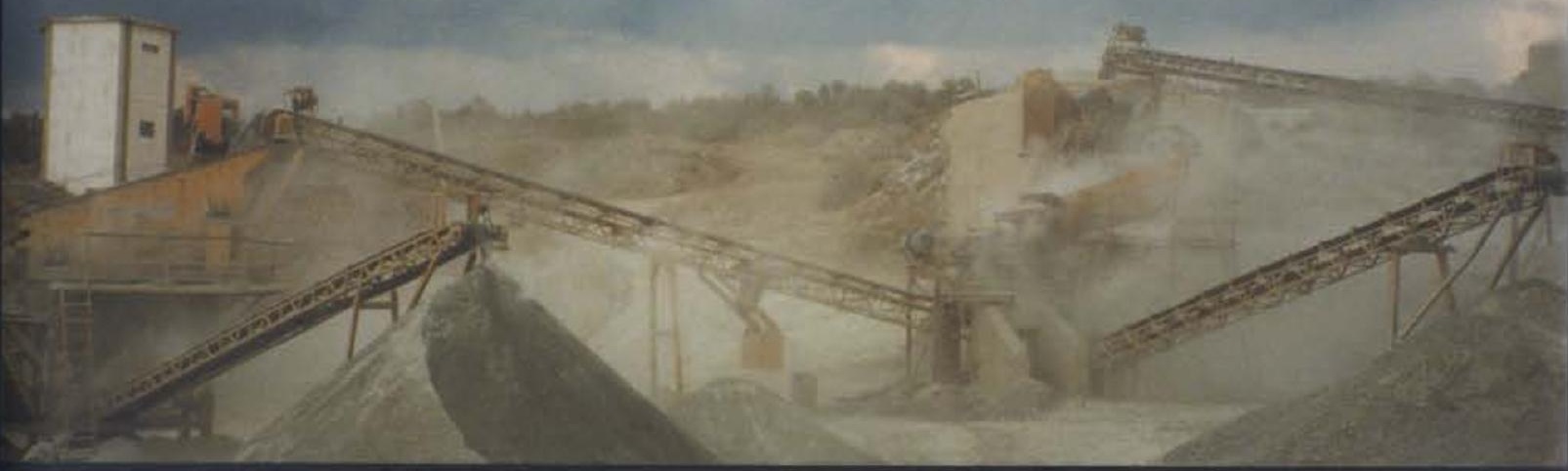




\title{
MULTI-SCALE GEOMETRICAL ANALYSIS OF FRACTURE NETWORKS IN GRANITE MASSIFS AND ITS APPLICATION TO LANDFILL SITE SELECTION
}

\author{
António Mateus ', Mário Abel Gonçalves ${ }^{1}$, \\ Fernando O. Marques ${ }^{2}$, Fernando Monteiro Santos ${ }^{3}$
}

KEY WORDS: fracture networks, multi-scale analysis, fractal geometry, granite massifs, waste disposal, landfill.

Palavras Chave: redes de fracturas, análise multi-escala, geometria fractal, maciços graníticos, deposição de resíduos, aterros sanitários.

\begin{abstract}
In the present work some numerical approaches are tested in order to comprehensively characterise the multi-scale geometry of the fracture network showed by a Variscan granite massif where a recent landfill is operating. The obtained results strongly suggest that the spatial distribution of fractures at different scales, particularly those sets that are strongly connected, must be considered in any technical solution concerning the minimisation and control of leachate leaking and dispersion via systematic and detailed monitoring. It is also shown that proper scaling of many of the geometric features displayed by natural fracture networks can be assessed by means of fractal methods, thus providing insights for predicting the character of fractures in unexposed domains of the rock mass, and supplying significant information to be used in fluid flow modelling. All these tasks are critical for a careful selection of acceptable sites for landfills construction on top of granite massifs as well as to design solutions to many problems concerning eventual leachate leaking and dispersion around dump cells.

' Dep. Geologia \& CREMINER, Fac. Ciências da Univ. Lisboa, Ed. C2, Piso 5, 1749-016 Lisboa

${ }^{2}$ Dep. Geologia \& LATTEX, Fac. Ciências da Univ. Lisboa, Ed. C2, Piso 5, 1749-016 Lisboa

${ }^{3}$ Dep. Física \& C. Geofísica, Fac. Ciências da Univ. Lisboa, Ed. C8, Piso 3, 1749-016 Lisboa
\end{abstract}




\section{RESUMO: Análise geométrica multi-escala de redes de fracturas em maciços graníticos e sua aplicação à selecção de locais para aterros sanitários}

Neste trabalho testam-se algumas abordagens numéricas com vista à caracterização geométrica multi-escala da rede de fracturas apresentada por um maciço granítico varisco onde se localiza um aterro sanitário recente. Os resultados obtidos indicam que qualquer solução técnica visando a minimização e controlo de fluxos de lixiviados e respectiva dispersão via monitorização sistemática do local intervencionado, deverá considerar a distribuição espacial de fracturas a diferentes escalas, especialmente as que constituem famílias de estruturas fortemente conectadas. Mais revelam que as extrapolações de escala poderão ser realizadas com base em métodos de análise fractal de diversos parâmetros geométricos, cujos resultados se afiguram determinantes na predição das características da rede de fracturas em domínios não aflorantes do maciço rochoso, fornecendo igualmente informações importantes ao desenvolvimento de modelos de escoamento de fluidos. Estes dados revelam-se críticos na selecção criteriosa de locais aceitáveis para a construção de aterros sanitários em maciços graníticos, assim como na pesquisa de soluções para muitos problemas relacionados com a eventual libertação e dispersão de lixiviados em torno das células de deposição de resíduos.

\section{INTRODUCTION}

Large inland areas of Portugal are dominated by strongly fractured Variscan granites and these rocks can hardly be circumvented when the future search for new disposal sites occurs as a response to the continuously increase of waste production (more than $30 \%$ in the last decade). The need of an accurate evaluation of these granite massifs for landfill engineering is obvious but, in practice, this apparently simple task may put some serious problems. In general, such evaluation is routinely based on factors that significantly reduce the dispersion of dissolved substances in ground and surface waters, where its effectiveness is a function of the ability to limit the volume of water that can penetrate the covered granite surface. This approach aims at minimise and retard the release and dispersion of pollutants to the environment. Accordingly, the multi-scale characterisation of the fracture network showed by granites is essential, regardless of the approach to evaluate and model the flow and transport pathways in such rocks.

The characterisation of natural fracture networks may involve different procedures, the most common are based on: 1) structural criteria, allowing the identification of different families existing within a fracture set through data inspection on the stereographic net; 2) spatial statistics, through the spatial analysis 
of geometrical characteristics of fracture networks (DEUTSCH \& JOURNEL, 1998); and 3) the characterisation of non-uniform fracture distributions by means of fractal geometry, once proven the scale invariance of fracture statistics (FALCONER, 1997, ZHANG et al., 1996; MARGOLIN et al., 1996; SAKellariou et al., 1991, BARTON, 1995; PAREDES \& ElorZA, 1996; TURCotTe, 1997).

The present work evaluates the fractal nature of the fracture network displayed by a Variscan granite massif located near Braga (N Portugal), where a recent landfill is operating. The spatial distribution and the major geometrical characteristics shown both by the lineament patterns and the mapped fracture networks at different scales were analysed by means of box counting and box density procedures. Additionally, the fracture spacing and density distributions are examined for several fractured granite outcrops. Models of fractal fragmentation are also briefly re-visited and tested using the obtained data. Finally, the procedures used in the multi-scale geometrical analysis are discussed, concerning their relevance in any scientific-technical approach designed for the selection of waste disposal sites on top of granite massifs and for the resolution of problems related to leachate leaking and dispersion.

\section{GEOLOGICAL SETTING}

The Braga region (N Portugal) is largely dominated by porphyroid granites dated at $c a .318 \mathrm{Ma}$ by U/Pb method (DiAS et al., 1998). A distinct fracture network can be easily recognised in this region, regardless of the observation scale, strongly controlling the major geomorphic features. The lineament pattern identified by means of satellite image interpretation at 1:50000 scale (fig. 1) displays good geometrical agreement with that obtained for the study area through vertical aerial photograph analysis at 1:23000 scale (fig. 2). Mapping of the fracture network at 1:25000 scale (fig. 3) shows that many of the interpreted lineaments indeed correspond to fault zones, or to strongly fractured rock domains, although their recognition and follow-up in the field may be severely compromised both in areas of intensive agricultural activity and of furzy covering. The majority of the mapped fractures are sub-vertical and the analysis of their direction using contoured projections reveals that four main families are present: $\mathrm{N} 70^{\circ} \pm 15^{\circ}, \mathrm{N} 0 \pm 5^{\circ}, \mathrm{N} 20^{\circ} \pm 10^{\circ}$ and $\mathrm{N} 160^{\circ} \pm 10^{\circ}$ (see MARQUES et al., 2001 for details).

The landfill is located on a structurally controlled ridge, by the influence of sub-vertical fractures and faults with directions ranging between ENE-WSW and E-W. Locally, the NW-SE and N-S fractures and faults are common and form intricate intersection patterns with the prevailing ENE-WSW to E-W systems. Detailed geological mapping of this sector is, however, seriously constrained because of the works related to landfill operation and of the furzy areas distribution. 


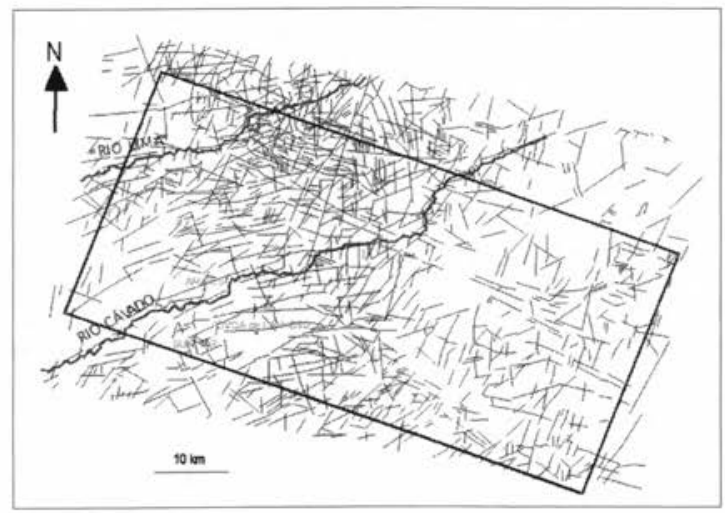

Fig. 1 - Satellite image interpretation of the lineament pattern shown by the region around the study area. The rectangle bounds the selected domain for fractal analysis.

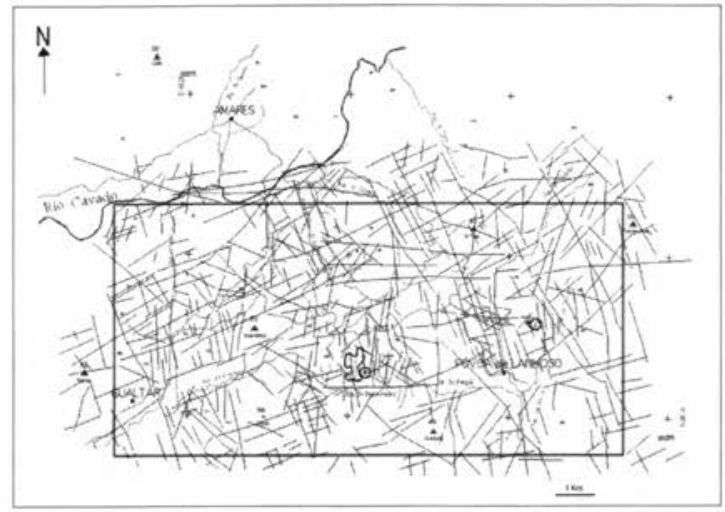

Fig. 2 - Vertical aerial photograph interpretation of the lineament pattern in the study area, which includes a recent landfill facility (B) and an old sealed dump (C); the rectangle bounds the selected domain for fractal analysis.

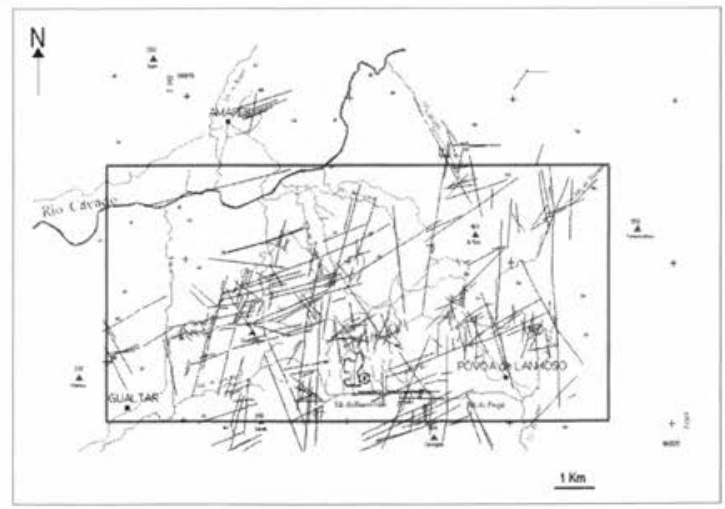

Fig. 3 - Fracture network of the study area; $\mathbf{B}$ and $\mathbf{C}$ as in fig. 2. The rectangle bounds the selected domain for fractal geometry analysis. 
Figure 4 considers just the granite outcrops displaying more than one fracture family that can be marked at 1:10000 scale; in these sites, a systematic record of fault/ fracture spacing were also performed along directions sub-perpendicular to the strike of the dominant family. During fieldwork strongly fractured rock domains were also identified and characterized in detail; one of them was mapped at 1:100 scale (fig. 5). These rock domains comprise usually many clusters of small length, mesoscopic fractures that often appears to be strongly connected.

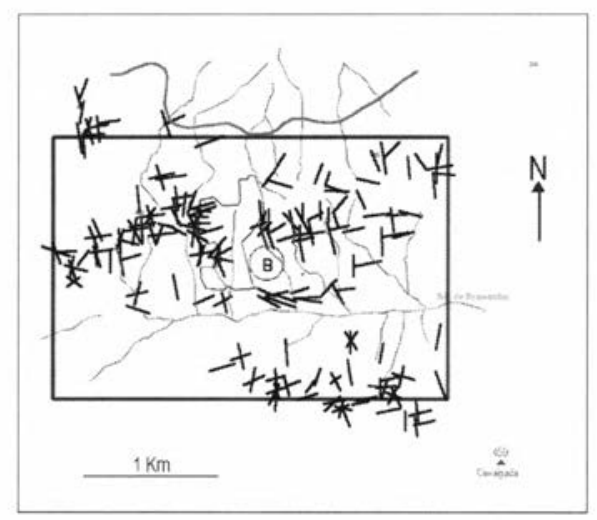

Fig. 4 - Distribution of the main mesoscopic fracture sets identified in granitic outcrops around the landfill facility (B). The rectangle bounds the selected domain for fractal geometry analysis.

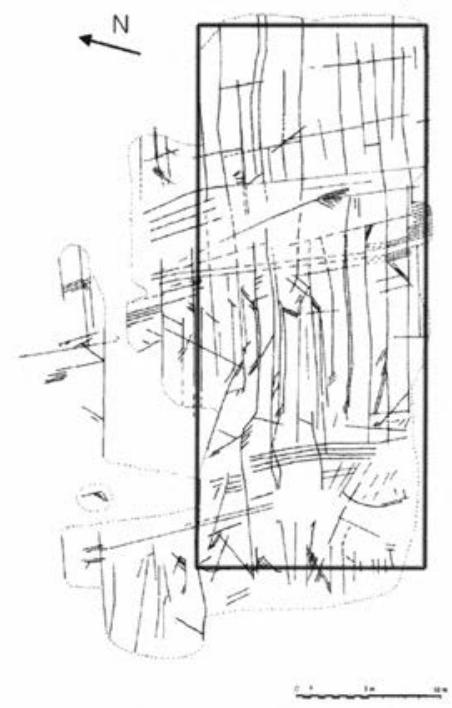

Fig. 5 - Map of a representative, strongly fractured granitic outcrop located in the area adjoining landfill facility. The rectangle bounds the selected domain for fractal geometry analysis. 
The available data for the site also comprise results from geo-electrical surveys and detailed geochemical analyses of water, soil and sediments; these are however beyond the scope of the present text but are fully reported in MATEUS et al. (2002), GONÇALVES et al. (2002a, b; in press), Figueiras et al. (2002; sub.) and MOTA et al. (sub.).

\section{DATA COLLECTION AND CALCULATION PROCEDURES}

The geometrical fractal analysis of the fracture network took into account data from different sources: lineament patterns from satellite image and aerial photograph interpretation and fracture field maps. The distribution of fracture spacing for each family was also examined with data from the 1:25000 and 1:100 maps along evenly spaced scan lines; these results were subsequently compared with the ones obtained in the field along selected sampling directions in well-exposed fractured rock domains. Additionally, the spatial distribution of fracture intersections on 1:25000, $1: 10000$ and 1:100 maps was analysed, in order to better characterise the geometry of fracture patterns. The analysis of fracture length distributions was not carried out given the problems usually faced during geological mapping. In fact: $i$ ) it is often difficult to interpret whether or not two fracture traces separated by a covered area represent the same discontinuity; ii) failures in the connectivity identification of distinct fracture trace exposures will result in underestimation of fractal dimensions; and iii) even in a completely exposed rock domain, fracture traces may be systematically biased if the map represents the loci of displacements greater than some threshold value. The systematic analysis of fracture apertures was also impracticable because of the great difficulty faced in measuring accurately this parameter in situ, and of the large variation that it typically shows along a given fracture.

\subsection{COMPUTATION OF FRACTAL DIMENSION}

The fractal dimension of a set of fracture traces distributed in a plane can be determined by different ways. In this work, box dimension $\left(D_{B}\right)$ measures were computed by using box sizes $\delta$ that follow the geometric progression $0.5,1,2$ and $4 \mathrm{~cm}$. The number of boxes with side length $\delta$ necessary to cover the fracture network $-\mathrm{N}(\delta)$ - for the entire range of $\delta$ values provides a mean to estimate how much space is filled by the whole network, given the proportionality between $\operatorname{logN}(\delta)$ and $\log \delta($ e.g. BARTON, 1995). The slope of the fitting linear regression between $\log \delta$ and $\log \mathrm{N}(\delta)$ estimated by the least-squares method is $\mathrm{D}_{\mathrm{B}}$, and the error in its determination can be as great as 0.05 (BARTON, 1995). 
The box density dimension $\left(\mathrm{D}_{\mathrm{BD}}\right)$ was also calculated for each case following the method proposed by LA POINTE (1988) and preserving the same range of linear box sizes; details on the algorithm used can be found in LA POINTE (1988). A similar procedure was applied to the analysis of the fracture intersections distribution, keeping in mind that, in this case, $\mathrm{D}_{\mathrm{BD}}$ will measure the variation on the spatial clustering of mesoscopic fracture connectivity that, essentially, represents the main input or output rock domains of water flow (regarding their geological and/or geomorphic setting).

Fracture spacing is the average distance between adjacent pairs of discontinuities belonging to the same family, as measured between points along a given scan line that intersects the fracture traces. Scan lines were selected such that all set of fractures of different directional families have high angles relative to the scan line. Since distance between fractures is the shortest distance as measured perpendicular to each fracture, all data needed to be post-processed, apart from determining fracture strike and position. Therefore, all fractures were grouped into classes of different directions, having such directions been chosen according to field data. The classes ranged within $\pm 20^{\circ}$ from the chosen direction, and were allowed to overlap $5^{\circ}$ over those next-positioned; in this way, some fractures counted equally to two classes of fractures. After such grouping, the average strike was determined and the spacing was averaged taking all values between each adjacent fracture as measured perpendicular to that average strike; the fracture density results as the reciprocal of the average spacing thus obtained.

\subsection{FragmentaTion MODELS}

Assuming that fragmentation probability is scale invariant, ALLĖGRE et al. (1982) and TURCOTTE (1986) developed models of fractal fragmentation using the Renormalization Group (RG) method. The latter author also demonstrated that the fractal dimension (D) of fragments distribution is independent of the volume ratio chosen in the RG approach, being, consequently, a good scale measure of the critical probability of fragmentation. Proceeding to a successive cell division until the $n^{\text {th }}$ order, the probability that an $n$-order cell have to generate fragments of $(n+1)$-order, $\mathrm{P}_{\mathrm{n}}$, is given by $\mathrm{D}=\log 8 P_{n} / \log 2$ (TURCotTE, 1986). Defining the topological conditions for which the elements of an $n$-order cell are fragile, one may subsequently calculate the probability of the event, setting $P_{n}$ as a function of $P_{(n+1)}$ and, subsequently, determine the critical probability of fragmentation $\left(\mathrm{P}_{\mathrm{C}}\right)$. Assuming a fragmentation model where a cell is considered fragile whenever: $i$ ) a "pillar" of sound elements (not permeated with micro-fractures) does not join two faces of an n-order cell (ALLÈGRE et al., 1982), or ii) a set of fragile cells is present and materialise a weakness plane in the lower order cell (TURCOTTE, 1986), two 
different polynomial expressions result for $\mathrm{P}_{\mathrm{n}}$ as a function of $\mathrm{P}_{(\mathrm{n}+1)}$ and, consequently, two different $\mathrm{P}_{\mathrm{C}}$ values can be calculated. A simple inspection of fracture networks in natural systems reveals, however, that not all of the weakness surfaces existing in a rock volume play equivalent roles in the fracturing processes. In fact, just those conveniently oriented to a given stress configuration are consequential, regardless the scale of brittle yielding and discarding the important effects of fluid pressure. From this, a different fragile criterion can be stated - an $n$-order cell will be fragmented only if the fragile elements materialises a weakness plane with a certain direction (MATEUS \& GONÇALVES, 1993) - thus resulting in a new topological configuration and a variation of the fragmentation model reported by TURCOTTE (1986), described by a different polynomial expression

$$
P_{n}=P_{(n+1)}^{8}-8 P_{(n+1)}^{7}+24 P_{(n+1)}{ }^{6}-32 P_{(n+1)}{ }^{5}+16 P_{(n+1)}{ }^{4}
$$

for which $\mathrm{P}_{\mathrm{C}}$ is 0.718 . The derived $\mathrm{D}$ value, being equal to 2.52 , agrees with the range of fractal dimensions reported in many studies that characterise fragmental distributions caused by natural and artificial fracturing processes $(2.5 \leq \mathrm{D} \leq 2.6$; for details see, e.g., TURCOTTE, 1997 and references therein).

In the present work, $\mathrm{P}_{\mathrm{n}}$ calculation accepts $\mathrm{D}$ as equivalent to $\mathrm{D}_{\mathrm{BD}}$ obtained for the 1:25000, 1:10000 and 1:100 fracture maps. The fragmentation model of Mateus \& Gonçalves $(1993)$ is considered for $P_{C}$ definition. Therefore, if $P_{n}$ values remain below 0.718 , the rock mass will become more and more sound as $n$ decreases, since $\mathrm{P}$ will tend quickly to 0 . On the contrary, if $\mathrm{P}_{\mathrm{n}}$ values are above 0.718 , the rock mass will experience strong and self-similar fragmentation, because $\mathrm{P}$ will tend rapidly to 1 as $n$ decreases.

\section{RESULTS AND DISCUSSION}

The obtained values of $\mathrm{D}_{\mathrm{B}}$ and $\mathrm{D}_{\mathrm{BD}}$ are reported in Table I, considering the lineament and fracture distributions for different scales, as well as the respective fracture intersection distributions. For each case, the correlation coefficient $(\rho)$ of the fitted least-square regression line between $\log \mathrm{N}(\delta)$ and $\log \delta$ is shown.

Inspection of Table I reveal that all of the studied distributions display $\log \mathrm{N}(\delta)$ $\log \delta$ relationships very well described by straight lines with $\mathrm{r}$ values equal to 1.000 for lineament patterns, ranging from -1.000 and -0.991 for fracture networks, and scattered between $-1,000$ and -0.972 for fracture intersection arrangements.

Focusing our attention on $\mathrm{D}_{\mathrm{B}}$ values, it is worth noting the large space occupied by lineament patterns $(1.98 \pm 0.01)$, whose self-similarity is convincing since the obtained difference $(0.02)$ is within the estimation error of the used method. 
Table I - $D_{B}$ and $D_{B D}$ values for the spatial distributions of lineaments, fractures and fracture intersections at different scales

\begin{tabular}{l|c|c|c|c|c}
\hline & $\mathbf{D}_{\mathbf{B}}$ & $\rho$ & $\mathbf{D}_{\mathbf{B D}}$ & $\rho$ & $\mathbf{P}_{\mathbf{n}}$ \\
\hline $\mathrm{A}$ & & & & & \\
$1: 50000$ & 1.99 & -1.000 & 2.61 & -1.000 & \\
$1: 23000$ & 1.97 & -1.000 & 2.64 & -1.000 & \\
\hline $\mathrm{B}$ & & & & & \\
$1: 25000$ & 1.80 & -0.999 & 2.40 & -0.993 & 0.799 \\
$1: 10000$ & 1.61 & -0.997 & 2.12 & -0.991 & 0.708 \\
$1: 100$ & 1.92 & -1.000 & 2.62 & -0.998 & 0.875 \\
\hline $\mathrm{C}$ & & & & & \\
$1: 25000$ & 1.30 & -0.993 & 1.94 & -1.000 & \\
$1: 10000$ & 1.10 & -0.980 & 1.80 & -0.972 & \\
$1: 100$ & 1.41 & -0.985 & 1.95 & -0.989 & \\
\hline
\end{tabular}

A: Lineament patterns; B: Fracture networks; C: Fracture intersection distributions.

A different kind of problems can, however, be stated when $\mathrm{D}_{\mathrm{B}}$ values of fracture networks are considered. In fact, although the dimension of the fracture network mapped at 1:100 scale is in acceptable agreement with those that characterise lineament patterns (being equal or slightly above the error involved in $D_{B}$ estimation), thus supporting the self-similar nature of the study distributions, the significant differences found for the remaining cases should be properly explained. For the fracture network mapped at 1:25000 scale, the lower dimension is clearly a result of geological sampling, since it was not carried out any tentative to extrapolate data between outcrops separated by furzy fields or by areas subjected to anthropogenic activity; it will be shown hereafter that the consistency between $\mathrm{D}_{\mathrm{BD}}$ values for the distribution of fracture intersections will support also this interpretation. Sampling problems intimately related to the constraints imposed by natural outcropping distribution may also be invoked to explain the dimension of the fracture network mapped at 1:10000 scale. It is, nevertheless, believed that this lowest $\mathrm{D}_{\mathrm{B}}$ value (1.61) records preferentially the influence of the used mapping criteria: only setting down the mesoscopic fractures observed in scattered outcrops with more than one fracture set, whose spatial continuity was guaranteed at 1:10000 scale. The effects of deficient geological sampling and/or of the imposed mapping criteria, lead to an incomplete record of the fracture network and justify the obtained discrepancy between $D_{B}$ values that characterise the distributions of fracture intersection at the three scales.

Box density dimensions for lineament patterns and fracture networks vary, as expected, between 2.00 and 3.00. The spatial distribution of lineaments is characterised by $\mathrm{D}_{\mathrm{BD}}$ values of 2.61 and 2.64 . The slightly higher dimension obtained for the photo-interpreted pattern at 1:23000 scale is in good agreement 
with its tendency to have anisotropic blocks (due to the clear predominance of ENE-WSW to E-W lineaments), suggesting also that there are more blocks per unit area in this pattern, and so, a better connection between its elementary structural elements. Note that the pattern resulting from the satellite imaging interpretation shows a heterogeneous spatial distribution of lineaments, being also difficult to qualitatively identify which is the dominant set of directions.

It is particularly interesting to examine $\mathrm{D}_{\mathrm{BD}}$ values concerning fracture networks at different scales, since they are lower than those calculated for lineaments distribution and vary significantly (from 2.12 to 2.62 ). The reasons for such difference and variation are diverse. The fracture network with the lowest dimension corresponds to that one mapped at 1:10000 scale, clearly having the fewest number of mesoscopic fractures and blocks; again, this is interpreted as an effect of the criteria used during mapping and of the outcrop distribution. Comparison between $\mathrm{D}_{\mathrm{BD}}$ values concerning fracture distributions at 1:100 and 1:25000 scales (2.62 and 2.40 , respectively) illustrates a difference that is mainly ascribable to sampling problems in the latter map, as a result of observation gaps that prevented the acquisition of geological data. The spatial distributions of fracture intersections at both scales are, however, characterised by identical $\mathrm{D}_{\mathrm{BD}}$ values (1.95 and 1.94, following the order aforementioned), thus suggesting a self-similar nature for the examined fracture network. In this perspective, the lower dimension obtained for the spatial distribution of fracture intersections at 1:10000 scale (1.80, corresponding also to the worst least-squares fitting, i.e. -0.972) is explained as a direct consequence of the adopted mapping criteria.

Fracturing in several granite outcrops around the landfill facility is really more intense than in others located very close to the dump cells, leading to the formation of many blocks. This does not mean, however, that the selected area for waste disposal is totally appropriate. By the contrary, the suggested self-similar nature of the fracture network above can also be inferred from the strong agreement between $\mathrm{D}_{\mathrm{BD}}$ values that characterise both the spatial fracture distributions mapped at 1:100 scale (2.62) and the lineament patterns at 1:23000 and 1:50000 scales (2.64 and 2.61, respectively). Therefore, the small range in $\mathrm{D}_{\mathrm{BD}}$ values can be justified in terms of slightly differences on blocks development and orientation in the three scales used. Note again that the higher fractal dimension obtained for the lineament pattern at 1:23000 scale records quite well the coupled effect of block tendency towards anisotropy and of the great number of blocks defined at this scale.

In Table I, the calculated $P_{n}$ values for the available fracture maps are also reported, making $\mathrm{D}$ in equation (1) equal to $\mathrm{D}_{\mathrm{BD}}$. According to the fragmentation model of MATEUS \& GONÇALVES (1993), the critical probability $\left(\mathrm{P}_{\mathrm{C}}=0.718\right)$ stands below the obtained $P_{n}$ for fracture networks mapped at 1:100 and 1:25000, and just slightly above $(0.01)$ the value concerning the incompletely recorded fracture distribution at 1:10000 scale. From this, it is clear that successively lower volumes 
of granite would behave predictably as brittle and comprise meso- and micro-fracture arrangements that preserve the geometry displayed by the mapped fracture networks.

The results of applying a Fourier transform spectral post-processor to the data collected at 1:10000 scale were rather noisy and non-interpretable; it was also virtually impossible to compute the covariance matrix. Data dispersion and scarcity may largely explain such results. Actually, data collection revealed a certain degree of clustering, which implied to have large non-sampled areas, and clusters of data points too close together. On average, distance between clusters is about half the mean cluster dimension. The tentative analysis of data points within each cluster also revealed to be insufficient because there were not enough points for the computation. Alternative methods will be essayed in the future, including conditional stochastic simulation (DEUTSCH \& JOURNEL, 1998) and a more adequate form of fractal interpolation (BARNSLEY, 1993; PUENTE et al., 2001).

\section{Conclusions}

Granitic massifs usually display non-uniform fracture networks of variable complexity that comprise strongly connected structural discontinuities responsible for different pathways through the rock, allowing water flow and, thus, the development of many chemical processes intimately related to water-rock interaction (such as precipitation-dissolution reactions, surface sorption, complexation, and transformation of organic compounds). This is chiefly true for Variscan granites located in the Iberian Massif, invariably affected by a prominent fracture network whose main sets were successively reactivated since the end of Variscan Orogeny until the present (MARQUES et al., 2002). In these geological settings, particular difficulties are expected in the determination of fracture geometry and flow physics, and so the identification and representation of the heterogeneous properties of the connected fracture network. These should be properly scaled in order to better constrain boundary conditions of numerical models of flow in fractured media.

In the present work, the fractal dimensions of lineament and fracture distributions show that satellite imaging and aerial photograph interpretation can be accurately used as a first approach to identify granite domains lesser fractured, hence more suitable for hosting landfill facilities. The available data reveal also that: 1) a detailed analysis of the fracture network can be carried out in well exposed granite outcrops, given the self-similar nature of the fracture network; 2) the development of a slightly block anisotropy is due to the predominance of the ENEWSW - E-W fracture set; 3 ) the most relevant variation in spatial clustering of fracture intersections involves the ENE-WSW - E-W and N-S - NNE-SSW fracture sets, and records the presence of many rock domains with strongly 
connected structures which can rule the major fluxes of water flow in granites; this is particularly important westwards and south-eastwards of the landfill; and 4) the granite comprise meso- and micro-fracture networks that preserve the geometry displayed by the mapped fracture networks.

\section{ACKNOWLEDGMENTS}

The financial support of FCT through the research project DIWASTE (PRAXIS/P/CTE/11028/1998) is appreciated.

\section{REFERENCES}

Allègre C. J., Le Mouell J. J., Prevost A. (1982). Scaling rules in rock fracture and possible implication for earthquake prediction. Nature, 287: 47-49.

BARTON C.C. (1995). Fractal analysis of scaling and spatial clustering of fractures. In Fractals in the Earth Sciences, C.C. Barton P.R. La Pointe, eds., Plenum Press, New York, 141-178.

Barnsley M.F. (1993). Fractals Everywhere. 2th Ed., Academic Press.

Deutsch, C, Journel, A. G. (1998). GSLIB: Geostatistical Software Library and User's Guide, $2^{\text {nd }}$ Ed., Oxford Univ. Press.

Dias G., Leterrier J., Ferreira N., Lopes Nunes J.E. (1998). U-Pb zircon and monazite geochronology of post-collisional Hercynian granitoids from the Central Iberian Zone (Northern Portugal). Lithos, 45: 349-369.

Falconer K. (1997). Techniques in Fractal Geometry. John Wiley \& Sons, Chichester.

Figueiras J., Gonçalves M.A., Mateus A., Marques F.O., Monteiro Santos F., Mota R. (2002). Monitorization of the initial stages of dispersion of pollutants around municipal waste disposal facilities. The Role and Fate of Trace Metals in Crustal Fluids, ESF Conference, Austria: 69-70.

Figueiras J., Gonçalves M.A., Mateus A., Marques F.O., Monteiro Santos F., Mota R. - Initial stages of pollutant dispersion around municipal waste disposal facilities; a case study in northern Portugal. Chemical Geology (submitted).

Gonçalves M.A., Cerqueira L., Figueiras J., Putnis C.V. (2002b). Use of micro-PIXE and SEM to study metal adsorption and artificial solid pahses in polluted environmental sediment samples. The Role and Fate of Trace Metals in Crustal Fluids, ESF Conference, Austria: 79-80.

Gonçalves M.A., Nogueira J.M.F., Putnis C.V., Figueiras J. (2002a). Metal and micro-organic pollutant partitioning between sediments and waste waters from a landfill. Geochim. Cosmochim. Acta, 66(S1): A285.

Gonçalves M.A., Nogueira J.M.F., Figueiras J., Putnis C.V., Almeida C. - Base-metals and organic content in stream sediments in the cicinity of a landfill. Applied Geochemistry (in press).

Howard J.H., Nolen-Hoeksema R.C. (1990). Description of natural fracture systems for quantitative use in petroleum geology. Amer. Ass. Petrol. Geol. Bull., 74: 151-162.

LA POINTE P. R. (1988). A method to characterize fracture density and connectivity through fractal geometry. Int. J. Rock Mech. Min. Sci. \& Geomech. Abstr., 25: 421-429. 
Margolin G., Berkowitz B., Scher H. (1998). Structure, flow, and generalized conductivity scaling in fracture networks. Water Resources Research, 34: 2103-2121.

Marques F.O., Mateus A., Amaral H., Gonçalves M.A., Tassinari C., Silva P., Miranda J.M. (2001). The Amares basin: an ENE-WSW graben formed by recent reactivation of the Late-Variscan fracture network? Comun. Inst. Geol. e Min., 88: 33-50.

Marques F.O., Mateus A., TAssinari C. (2002). The Late-Variscan fracture network in Central-Northern Portugal (NW Iberian): a re-evaluation. Tectonophysics, 359: 255-270.

Mateus A., Gonçalves M.A. (1993). Caracterização geométrica e distribuição fractal da fracturação adjacente à Falha da Vilariça no sector da Quinta da Terrincha (NE de Portugal). Gaia, 6: 43-58.

Mateus, A., Almeida, C., Monteiro Santos, F., Marques, F.O., Marques, F., Amaral, H., Figueiras, J., Miranda, J., Gonçalves, M.A., Silva, P., Mota, R. (2002) - Fluid flow in fractured rocks and its implications for waste disposal criteria. Research Project PRAXIS XXI/P/CTE/11028/98. Unpublished Final Report, Fundação para a Ciência e Tecnologia, Lisbon, 293 pp.

Mota R., Monteiro Santos F., Mateus A., Marques F.O., Gonçalves M.A., Figueiras J., Amaral H. - Geoelectrical study of a recent landill facility in a fractured crystalline basement. J. Applied Geophysics (submitted).

Paredes C., Elorza F.J. (1999). Fractal and multifractal analysis of fractured geological media: surface-subsurface correlation. Computers \& Geosicences, 25: 1081-1096.

Puente, C. E., Robayo, O., Diaz, M. C. \& Sivakumar, B (2001). A fractal-multifractal approach to groundwater contamination. 1. Modelling conservative tracers at the Borden site. Stochastic Environmental Research and Risk Assessment, 15:357-371.

Sakellariou M., Nakos B., MitsaKaki C. (1991). On the fractal character of rock surfaces. Int. J. Rock Mech. Min. Sci. \& Geomech. Abstr., 28, 6: 527-533.

TURCotTe D. (1986). Fractals and fragmentation. J. Geophys. Res., 91: 1921-1926.

Turcotte D. (1997). Fractals and Chaos in Geology and Geophysics. 2th Ed., Cambridge Univ. Press.

Zhang X., SANDERson D.J., Harkness R.M., LASt N.C. (1996). Evaluation of the 2D permeability tensor for fractured rock masses. Int. J. Rock Mech. Min. Sci. \& Geomech. Abstr., 33 (1): $17-37$. 